\title{
MASA DEPAN USADA BALI DALAM WACANA MODERNITAS
}

\author{
Ida Bagus Suatama \\ Program Studi Kesehatan Ayurweda Fakultas Kesehatan Universitas Hindu Indonesia, Denpasar Bali \\ * Corresponding author
}

\begin{abstract}
Abstrak
Modernitas menawarkan berbagai nilai baru yang berpotensi menggilas nilai-nilai tradisional, termasuk pada bidang kesehatan masyarakat. Fenomena ini juga terjadi dalam praktik pengobatan Usada Bali yang semakin terpinggirkan akibat hegemoni medis modern. Kendati demikian, eksistensi Usada Bali juga ditopang oleh kepercayaan masyarakat, sumber-sumber literatur, dan regulasi negara sebagai modal dasar pengembangannya. Ketiga modal ini terakumulasi dengan habitus, ranah, dan praktik sosial yang dinegosiasikan secara dialektis dalam pengobatan Usada Bali. Atas dasar itulah, optimalisasi kepercayaan masyarakat, pemosisian dalam wacana ilmiah, dan kapitalisasi regulasi negara menjadi dimensi penting yang menentukan masa depan Usada Bali dalam wacana modernitas.
\end{abstract}

Kata kunci: Usada Bali, wacana, modernitas.

\begin{abstract}
Modernity offers a variety of new values that have the potential to overwhelm traditional values, including in the field of public health. This phenomenon also occurs in the practice of the treatment of Usada Bali which is increasingly marginalized due to modern medical hegemony. Nevertheless, the existence of Usada Bali is also supported by public trust, literary sources, and state regulations as the basis for its development. These three capitals accumulate with habitus, the realm, and social practices that are dialectically negotiated in the treatment of Usada Bali. For this reason, optimizing public trust, positioning in scientific discourse, and capitalizing state regulations are important dimensions that determine the future of Usada Bali in the discourse of modernity.
\end{abstract}

Keywords: Usada Bali, discourse, modernity.

\section{Pendahuluan}

Masyarakat Bali pada umumnya percaya bahwa penyakit dapat disebabkan oleh kausa sakala dan niskala (Nala, 1993:2) atau kausa naturalistik dan personalistik (Foster dan Anderson, 1978:45). Etiologi ini berpengaruh kuat dalam diri masyarakat Bali sehingga menentukan pilihan pengobatannya. Terbukti ketika sistem pengobatan modern telah berkembang begitu pesat, kepercayaan masyarakat Bali terhadap kausa niskala tidak lantas hilang sehingga Usada Bali tetap menjadi alternatif pengobatan yang diganderungi masyarakat. Fenomena ini sejalan dengan pendapat Angela Hobart (dalam Mbete, dkk (Ed.), 1998:22), sebagai berikut.

"As long as the Hindu religion remains steadfest, people will continou to believe in the seen and unseen worlds, and there will be traditional healers ('suwene kanton langen indik kawentenan agama Hindu, tetep wenten percaya ring sakala niskala, taler wenten balian')"

Artinya:

E-Jurnal Widya Kesehatan ,Volume 1, Nomor ; 2 Oktober 2019 
Selama agama Hindu tetap teguh, orang akan terus percaya pada dunia yang terlihat (sakala) serta tidak terlihat (niskala), dan maka di situlah akan tetap ada pengobat tradisional (balian).

Pendapat di atas menegaskan bahwa eksistensi Usada Bali terkait erat dengan kepercayaan umat Hindu di Bali tentang keberadaan alam sakala dan niskala. Selama kepercayaan ini masih ada, maka balian akan tetap eksis. Pilihan berobat pada balian menjadi bagian tidak terpisahkan dari kepercayaan tersebut sehingga dalam kesadaran praksisnya, pasien tidak pernah sungguh-sungguh mempertimbangkan efektivitas dari pengobatannya. Hal ini memperkuat pendapat Foster dan Anderson (1996:48) bahwa menerima peran sakit merupakan kondisi yang tidak menyenangkan sehingga segala cara akan dilakukan untuk mencari kesembuhan atau paling tidak meringankan beban sakitnya. Kondisi ini memperbesar peluang eksisnya pengobatan Usada Bali sebagai alternatif yang memberikan harapan kesembuhan bagi pasien. Apalagi ketika pasien beranggapan bahwa medis modern juga tidak mampu memberi kepastian kesembuhan seperti yang diharapkan.

$$
\text { Walaupun secara intrinsik }
$$
kepercayaan terhadap balian berkaitan erat dengan kepercayaan fundamental terhadap etiologi sakala dan niskala, tetapi modernitas juga menawarkan nilai baru yang pada batasbatas tertentu dapat melunturkan kepercayaan tersebut. Tidak dipungkiri lagi bahwa modernitas membangun wacana medis dengan prinsip positivisme sebagai syarat validitas pengetahuan, seperti objektif, terukur, dan berlaku umum. Syarat-syarat ini tentu tidak seluruhnya terpenuhi dalam Usada Bali yang mengedepankan kepercayaan, sugesti, dan kemampuan subjektif pengobatnya. Oleh karenanya, marjinalisasi Usada Bali dalam wacana modernitas merupakan suatu keniscayaan terutama dalam konteks relasi pengetahuan dan kekuasaan. Akan tetapi, dewasa ini juga tumbuh kesadaran berbagai kalangan untuk mempertahankan, bahkan mengembangkan Usada Bali sebagai kearifan lokal yang dapat berpartisipasi dalam meningkatkan derajat kesehatan masyarakat. Artinya, terbuka peluang untuk menatap masa depan Usada Bali yang lebih baik dalam wacana modernitas. Hal ini menarik dicermati secara kritis terutama untuk menemukan potensi-potensi Usada Bali yang dapat dioptimalkan dalam konstruk budaya modern.

\section{Kajian Teoretik}

Kepercayaan masyarakat Hindu di Bali tentang etiologi sakala-niskala adalah basis eksistensi Usada Bali dalam wacana kesehatan (Nala, 1993; Hobart, 1998). Hal ini didukung kekayaan pengetahuan Usada Bali yang tersimpan dalam lontar-lontar, seperti Usada Buduh, Usada Cukildaki, Usada Dalem, Usada Kacacar, Usada Ila, Usada Kuda, Usada Kurantangbolong, Usada Manak, Usada Tiwang, Usada Rare, Usada Pamugpugan, Usada Pamugpug, Usada Budhakecapi, Usada Selik Sejati, Taru Pramana, dan lain sebagainya (Tim Fakultas Sastra Universitas Udayana, 2017). Artinya, Usada Bali sebagai sistem pengetahuan dan kearifan lokal Bali mempunyai modal dasar yang cukup kuat untuk dikembangkan. Apalagi dalam perkembangannya, pemerintah juga memiliki perhatian terhadap pengobatan

E-Jurnal Widya Kesehatan ,Volume 1, Nomor ; 2 Oktober 2019 
tradisional yang ditunjukkan melalui berbagai regulasi, seperti berikut.

(1) Undang-undang Nomor 36 Tahun 2009 tentang Kesehatan sebagai pengganti atas Undang-undang Nomor 23 Tahun 1992 tentang Kesehatan.

(2) Peraturan Pemerintah Republik Indonesia Nomor 103 tahun 2014 tentang Pelayanan Kesehatan Tradisional.

(3) Peraturan Menteri Kesehatan Republik Indonesia Nomor 9 Tahun 2016 tentang Upaya Pengembangan Kesehatan Tradisional.

(4) Peraturan Menteri Kesehatan Republik Indonesia Nomor 61 Tahun 2016 tentang Pelayanan Kesehatan Tradisional Empiris.

(5) Peraturan Menteri Kesehatan Republik Indonesia Nomor 37 Tahun 2017 tentang Pelayanan Kesehatan Tradisional Integrasi.

Ketiga aspek tersebut dapat dipandang sebagai modal potensial pengembangan Usada Bali dalam merespons wacana modernitas. Kepercayaan masyarakat menjadi modal para balian untuk mengembangkan kapasitas keagenannya sebagai pengobat. Kekayaan literatur Usada Bali menjadi sumber pengetahuan potensial bagi balian dan kalangan intelektual dalam pengembangan wacana ilmiah. Sementara itu, regulasi negara menciptakan modal struktural bagi pengembangan Usada Bali dalam wacana modernitas. Optimalisasi ketiga modal tersebut dapat dicermati dari perspektif teori praktik sosial yang mengedepankan dialektika agen dan struktur dalam arena produksi kultural (Bourdieu, 2010:211; Harker, dkk. (Ed.), 2009:xviii). Bourdieu (2010:211), menyatakan bahwa produksi kultural akan melibatkan habitus, ranah, dan modal yang berlangsung dalam praktik sosial yang dinyatakan dalam rumus generatif, “(Habitus x Modal) + Ranah $=$ Praktik".
Habitus adalah nilai yang meresap dalam pikiran dan perasaan seseorang yang mempengaruhi serta menentukan nilai selera seseorang. Secara dialektis, habitus ini menentukan kerangka tindakan individu sesuai ranah (field) dan modal (capital) yang dimiliki (Ritzer dan Goodman, 2005:522). Ranah, arena atau medan (field) menurut Bourdieu (Harker, dkk. (Ed.), 2009:9-10) adalah ranah kekuatan, yaitu satu arena dimana berbagai potensi eksis. Ranah kekuatan secara parsial bersifat otonom sebagai tempat memperjuangkan posisi-posisi. Di dalam ranah, orang-orang memperjuangkan berbagai modal yang menurut Bourdieu (Harker, dkk. (ed.), 2009:16), mencakup hal-hal material (modal ekonomi), atribut yang tidak dapat disentuh, tetapi mempunyai signifikansi kultural, misalnya prestise, status, dan otoritas (modal simbolik), serta modal budaya (selera bernilai budaya dan pola-pola konsumsi), misalnya properti, seni, dan bahasa. Berbagai modal inilah yang diperjuangkan dan dipertukarkan oleh para aktor untuk berbagai kepentingan dalam praktik sosial. Sementara itu, praktik menurut Bourdieu (dalam Harker dkk., 2009:18-19) adalah interaksi antara habitus dan ranah yang disebut, 'internalisasi eksternalitas' dan 'eksternalisasi internalitas'. Persamaan "(habitus $\mathrm{x}$ modal) + ranah $=$ praktik" mengganti setiap relasi sederhana antara individu dan struktur, dengan relasi habitus dan ranah yang melibatkan modal. Keterkaitan dari tiga aspek tersebut merupakan simpul praktik-praktik sosial sehingga kehidupan sosial adalah kontinuitas praktis tindakan individu dalam struktur.

\section{Pembahasan}

E-Jurnal Widya Kesehatan ,Volume 1, Nomor ; 2 Oktober 2019 


\section{A. Optimalisasi Kepercayaan Masyarakat}

Minat masyarakat terhadap pengobatan tradisional semakin meningkat dewasa ini. Tingginya minat masyarakat terhadap sistem pengobatan tradisional dapat dilihat dari pernyataan Kalangie (1994:129) berikut ini.

“... At the same time it would be foolish to assume that eventually traditional medicine and popular care will die or wither... First of all, jamu tonics and the like are believe in implicity by even educated Indonesian, physician included...".

('...pada saat yang sama adalah suatu kebodohan apabila menganggap pengobatan tradisional dan perawatan populer telah mati atau layu... Pertamatama, obat jamu dan sejenisnya, bahkan secara implisit masih dipercayai oleh orang Indonesia yang berpendidikan, termasuk dokter').

Makna pernyataan tersebut bahwa kepercayaan masyarakat Indonesia terhadap pengobatan tradisional tertanam begitu kuat, bahkan tidak tergantikan dengan sistem medis modern. Salah satu buktinya bahwa obatobatan tradisional, misalnya jamu, ternyata masih diminati masyarakat, termasuk orangorang berpendidikan dan dokter sekalipun. Kata 'orang berpendidikan' mewakili citra masyarakat yang terdidik secara modern atau mengacu pada manusia rasional. Apalagi dokter yang jelas merujuk pada profesi medis modern. Manakala orang berpendidikan dan dokter saja masih percaya dengan pengobatan tradisional, maka kepercayaan masyarakat umum tentu akan lebih kuat. Masih tingginya kepercayaan masyarakat tersebut tentu menjadi modal berharga dalam upaya mengembangkan Usada Bali ke depan. Hanya saja, diperlukan usaha secara serius dan sungguh-sungguh dari para pengobat Usada Bali (balian) terutama dalam mengoptimalisasikan kepercayaan tersebut.

Optimalisasi kepercayaan masyarakat dalam wacana modernitas tergantung cara seorang balian dalam membangun keunggulan kompetitif yang menentukan daya tawarnya. Daya tawar (bargaining position) terkait dengan pemosisian (positioning) aktor dalam perjumpaan-perjumpaan dengan struktur dan aktor-aktor lain. Dalam hal ini, balian sebagai aktor utama Usada Bali yang berada dalam struktur sosial modern, mau tidak mau, juga harus mengadaptasi kultur modern dalam menentukan nilai-nilai kompetensi keagenannya. Secara kultural, modernisasi mengisyaratkan tata nilai baru yang lebih menonjolkan peran individu pada isu seputar humanisme, demokrasi, dan partisipasi (Triguna, 2003:2). Artinya, modernisasi mengafirmasi nilai-nilai subjektif sehingga individu mempunyai kekuasaan yang lebih besar daripada struktur, kendati mereka juga tidak mungkin bergerak di luar struktur.

Dalam konteks Usada Bali, ini bermakna bahwa kesempatan dan peluang para balian untuk memanfaatkan kultur modern melalui kapasitas keagenan yang dimiliki cukup terbuka. Melalui adaptasi dialektis dengan kultur modern, maka seorang balian dapat menentukan posisinya secara efektif dalam industri jasa pelayanan kesehatan secara kompetitif. Otonomi subjek dalam struktur dan kultur modern meniscayakan pemosisian balian dalam ruang publik melalui penguasaan kepercayaan masyarakat tentang kesehatan. Oleh karena itu, kemampuan balian dalam menarasikan dirinya dan praktik pengobatan yang dijalankan, akan menentukan keberterimaan masyarakat terutama dalam

E-Jurnal Widya Kesehatan ,Volume 1, Nomor ; 2 Oktober 2019 
kesadaran praksisnya. Kesadaran praksis pasien untuk lekas sembuh dari penyakitnya dapat dijadikan orientasi para balian untuk mereproduksi wacana kesehatan, baik penyakit maupun penyembuhannya. Setidak-tidaknya, seorang balian dapat mengkapitalisasi kesadaran praksis pasien tersebut dengan menawarkan Usada Bali sebagai pilihan utama, alternatif, maupun komplemen dari upaya medis.

Penggunaan kekuatan supranatural (magico-religius) dalam sistem pengobatan Usada Bali merupakan keunggulan potensial para balian yang tidak dimiliki seorang dokter. Pasien yang mempercayai kekuatan supranatural akan merasakan kenyamanan psikis setelah diterapi balian. Kenyamanan psikis ini dibutuhkan pasien yang sedang mengalami kelemahan secara fisik dan mental sehingga dapat melahirkan energi baru untuk berjuang melawan penyakitnya. Selain itu, juga hubungan balian dengan pasien umumnya berlangsung lebih terbuka sehingga komunikasi interpersonal lebih mudah dibangun, dibandingkan medis modern yang cenderung bersifat teknis. Keunggulan ini penting dioptimalkan oleh para balian dalam menjalankan praktik pengobatannya sehingga mampu berkompetisi secara sehat dengan jasa layanan kesehatan yang lain. Dalam konstruk budaya modern yang mengutamakan rasionalitas, profesionalitas, dan materialisme, maka kemampuan seorang balian dalam memosisikan diri berdasarkan keunggulan kompetitifnya (competitive pride) merupakan sebuah keniscayaan. Dalam hal ini, masih tingginya kepercayaan masyarakat terhadap Usada Bali menjadi medan refleksivitas yang patut dioptimalkan ke depannya.

\section{B. Pemosisian dalam Wacana Ilmiah}

Tidak dapat dipungkiri bahwa modernitas yang bertumpu pada prinsipprinsip rasio, objektif, dan wacana ilmiah mengutamakan validitas serta otoritas pengetahuan yang mendasari berbagai praktik sosial. Sehubungan dengan itu, keberhasilan sistem medis modern dalam merebut simpati masyarakat tidak lepas dari wacana ilmiah yang dikembangkan melalui berbagai penelitian. Oleh karena itu, pemosisian Usada Bali dalam wacana ilmiah menjadi begitu penting dalam masyarakat modern. Hal ini tentu bukan hal yang sulit karena agama Hindu dan kebudayaan Bali memiliki pengetahuan kesehatan yang sangat maju, bahkan jauh sebelum medis modern berkembang, seperti ditunjukkan dengan keberadaan literatur Ayurweda dan Usada Bali yang mencakup berbagai jenis pengobatan.

Berkenaan dengan hal tersebut, studistudi ilmiah tentang Usada Bali tentunya harus dikembangkan. Oleh karenanya, peran dan partisipasi aktif lembaga pendidikan menjadi begitu penting bagi masa depan Usada Bali dalam wacana modernitas. Hal ini juga penting untuk merespons perkembangan global mengenai kebangkitan peran budaya sebagai paradigma baru yang menjadikan kekayaan budaya sebagai kekuatan pembangunan (Huntington dan Harisson, (ed.), 2006). Di bidang kesehatan, kesadaran mengeksplorasi pengetahuan kesehatan tradisional menjadi usaha yang mengesankan terutama di negaranegara dengan peradaban tinggi, seperti China dan India. Salah satunya disampaikan Hilmar Farid - Dirjen Kebudayaan, Kementerian

E-Jurnal Widya Kesehatan ,Volume 1, Nomor ; 2 Oktober 2019 
Pendidikan dan Kebudayaan RI - dalam Seminar Nasional bertemakan "Denpasar Kota Budaya Menuju Keadaban dan Kesejahteraan”, 27 Februari 2019, sebagai berikut.

"Sepanjang sejarah, industri farmasi modern itu berangkat dari pengetahuan tradisional, dan telah menghasilkan trilyunan. India sadar, dan ketika dia bikin traditional knwoledge digital library, itu dijadikan basis untuk menuntut balik perusahaan farmasi yang menggunakan pengetahuan nenek-moyangnya. 2000 tuntutan dilayangkan, 200 menang."

Pernyataan di atas mengisyaratkan

bahwa Usada Bali merupakan traditional knowledge yang harus diinventarisasi keberadaannya sekaligus dikembangkan dalam wacana ilmiah. Usaha ini setidak-tidaknya telah dilakukan oleh almarhum Prof. dr. I Gusti Ngurah Nala, MPH (selanjutnya disebut Prof. Nala) dan beberapa ilmuwan Bali lainnya. Prof. Nala dapat dianggap sebagai pioner pengembangan Usada Bali sebagai ilmu pengetahuan yang spesifik dan membawanya ke dalam panggung ilmiah dalam lembaga pendidikan tinggi. Hal ini tampak dari sejumlah karya beliau, seperti Usada Kencing Manis (1991), Usada Bali (2002), dan Aksara Bali dalam Usada (2006). Prof. Nala juga membidani lahirnya Program Diploma III Usada yang bernaung di bawah Fakultas Matematika dan Ilmu Pengetahuan Alam (F.MIPA), Unhi Denpasar pada tahun 2004, yang sekarang bertransfromasi menjadi Program Studi Ayurweda, Fakultas Kesehatan UNHI Denpasar.

Program Studi Ayurweda UNHI Denpasar dapat dipandang sebagai institusi strategis yang mampu melakukan pemosisian Usada Bali dalam wacana ilmiah. Pada satu sisi, otoritasnya sebagai lembaga pendidikan tinggi memberikan jaminan bahwa pengetahuan yang dihasilkan dapat dipertanggungjawabkan kadar keilmiahannya. Di sisi yang lain, lembaga ini merupakan institusi satu-satunya yang memiliki perhatian khusus terhadap Ayurveda dan Usada Bali sebagai kearifan lokal Hindu-Bali. Melalui kajian-kajian ilmiah itulah, pengobatan tradisional dapat berterima dengan masyarakat modern yang lebih mengutamakan rasionalitas dan meniscayakan posisinya dapat disejajarkan dengan medis modern. Kesejajaran posisi ini dipandang penting untuk membuka peluang pengobatan Usada Bali dapat berkolaborasi dengan medis modern untuk menunjang peningkatan kualitas kesehatan masyarakat.

Selain institusi pendidikan, keterlibatan kelompok-kelompok sekunder yang memiliki minat dan perhatian pada pengobatan tradisional Bali juga harus didorong partisipasinya. Hal ini seturut dengan struktur masyarakat modern yang salah satunya ditandai dengan terbentuknya kelompok-kelompok sekunder, pola-pola sosial baru, partisipatoris, pembentukan kelompok referensi baru, dan pemisahan dari kelompok tradisional (Abraham, 2007:207). Pendirian organisasi Ikatan Pengobat Tradisional Indonesia (IPATRI) yang berpusat di Bali pada tahun 2007, dan dipimpin oleh Prof. Dr. dr. Nyoman Adiputra, PFK, M.O.H, yang notabene adalah seorang ahli medis modern (dokter). Bukan hanya itu, juga jajaran pengurusnya terdapat sejumlah dokter dan unsur pejabat pemerintah dari jajaran Kementerian Kesehatan, baik pusat maupun daerah. Selanjutnya, fungsi organisasi IPATRI dapat dilihat dalam Program Jangka Panjang yang ditetapkan, sebagai berikut.

E-Jurnal Widya Kesehatan ,Volume 1, Nomor ; 2 Oktober 2019 
(1) Mengembangkan Ilmu Kesehatan Tradisional Indonesia;

(2) Meningkatkan citra profesi Pengobat Tradisional Indonesia sebagai pelayan kesehatan;

(3) Membina praktik pelayanan kesehatan Tradisional Indonesia bagi para anggota atas dasar standar kaidah pengobatan yang baik;

(4) Membantu pemerintah dalam menapis masuknya tenaga kesehatan tradisional asing maupun obatnya yang merugikan di Indonesia;

(5) Mendirikan pusat penelitian, pengkajian, dan informasi mengenai pengobatan ramuan tradisional Indonesia khususnya di bidang bahan tumbuhan, hewan, sediaan sarian (gelenik), mineral atau campuran dan bahan-bahan tersebut;

(6) Mendirikan perpustakaan di bidang Ilmu Kesehatan Tradisional Indonesia;

(7) Mempersiapkan berdirinya Akademi/Fakultas Ilmu Kesehatan Tradisional Indonesia bersama Akademi, Universitas Negeri/Swasta, maupun dengan Departemen Kesehatan. Untuk pertama kali akan bekerjasama dengan Fakultas Pertanian Institut Pertanian Bogor;

(8) Inventarisasi tanaman berkhasiat obat, maupun cara pembuatan yang dilakukan berdasarkan etnis, bekerjasama dengan Balitbang Depkes, BPTO Tawangmangu, Balitro, dan Depdiknas (Majalah Kesehatan Suara Balian, volume 1 2008, hal.7).

Dari fungsi-fungsi tersebut dapat dipahami bahwa tujuan didirikannya IPATRI adalah memperjuangkan pengobatan tradisional termasuk Usada Bali supaya sejajar dengan medis modern, baik teknis maupun etis. Dalam fungsi tersebut tampak jelas bahwa wacana ilmiah menjadi dimensi penting yang digarap, seperti pengembangan ilmu kesehatan tradisional, standarisasi pelayanan dalam praktik pengobatan, rencana pendirian pusat kajian dan informasi, perpustakaan ilmu kesehatan tradisional, bahkan rencana pendirian akademi atau fakultas kesehatan tradisional. Hal ini menegaskan bahwa pemosisian Usada Bali dalam wacana ilmiah menjadi gagasan penting di balik pendirian organisasi tersebut yang dapat dipandang sebagai respons terhadap masa depan Usada Bali dalam wacana modernitas.

\section{Kapitalisasi Regulasi Negara}

Negara modern (modern state) mencakup dua fungsi sekaligus, yakni negara hukum (reechsstaat) dan negara kesejahteraan (welfare state). Giddens (1998:100), menyatakan bahwa fungsi tersebut menjadikan negara mempunyai sifat intervensionis sehinigga negara selalu mengambil bagian dalam setiap aktivitas masyarakat dengan alasan meningkatkan kesejahteraan umum. Demikian halnya dalam bidang kesehatan, negara hadir melalui undang-undang dan peraturan lainnya untuk mengatur aktivitas kesehatan masyarakat. Regulasi negara di bidang kesehatan sebagai pengatur aktivitas kesehatan merepresentasikan negara hukum (reechsstaat), sedangkan regulasi negara sebagai landasan pembangunan kesehatan merepresentasikan negara kesejahteraan (welfare state). Dalam fungsi hukumnya, regulasi memiliki sifat memaksa (coersive) karena setiap aktivitas kesehatan harus tunduk pada aturan yang ditetapkan. Namun dalam fungsi kesejahteraannya, regulasi bertujuan mendorong terciptanya kesadaran masyarakat untuk meningkatkan kualitas kesehatannya.

Regulasi negara bidang kesehatan terkait dengan pengobatan tradisional telah diatur dalam undang-undang dan peraturan lainnya. Hal ini bergayung-sambut dengan dukungan pemerintah, akademisi, dan penggiat 
Usada Bali. Keberadaan pengobatan tradisional tampaknya juga diapresiasi positif oleh Kementerian Kesehatan RI sebagai representasi negara di bidang kesehatan. Hal ini dapat dilihat dari pernyataan Dr. Dra. Agusdini Banun Saptaningsih - Direktur Produksi dan Distribusi, Direktorat Jenderal Kefarmasian dan Alat Kesehatan, Kementerian Kesehatan RI - sebagaimana dikutip Jawa Pos, 2 November 2018, yang pada prinsipnya menyampaikan sebagai berikut.

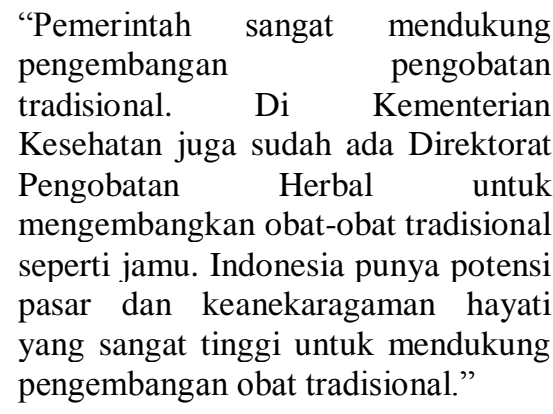

Dari pernyataan tersebut dapat dipahami bahwa Kementerian Kesehatan RI memiliki perhatian yang serius terhadap pengembangan pengobatan tradisional. Salah satunya ditandai dengan pembentukan Direktorat Pengobatan Herbal yang menangani secara khusus kekayaan obat-obatan herbal di Indonesia yang dapat dioptimalisasikan dalam upaya peningkatan kualitas kesehatan masyarakat secara utuh dan menyeluruh. Pengembangan obat-obatan herbal yang diapresiasi oleh Kementerian Kesehatan RI tentu memiliki korelasi dan relevansi dengan Usada Bali yang salah satu metodenya adalah menggunakan tanaman (taru). Dukungan pemerintah untuk mengembangkan obatobatan herbal sesungguhnya menunjukkan keselarasan makna dengan penguatan eksistensi Usada Bali. Apalagi regulasi negara di bidang kesehatan juga memberikan kewenangan pada pemerintah daerah, baik provinsi maupun kabupaten/kota untuk mengembangkan pengobatan tradisional. Di sini, kekuasaan bergerak melalui kapilerkapiler yang lebih kecil sehingga menyentuh masyarakat terbawah.

Wacana Gubernur Bali untuk menjadikan Bali senagai pusat herbal dunia dan mengembangkan pengobatan usada yang bersumber dari Ayurveda (Jawapos, 2 November 2018); wacana membuka loket khusus bagi pengobat tradisional di rumah sakit; dan mensertifikasi balian yang akan praktik di rumah sakit (detiknews.com, 9 November 2018), merupakan beberapa bentuk dukungan Pemerintah Daerah Provinsi Bali untuk memperkuat eksistensi Usada Bali. Dalam wacana tersebut tampak bahwa penguatan eksistensi Usada Bali dikelompokkan menjadi 4 (empat) simpul wacana, yaitu (1) Bali sebagai pusat herbal dunia merefleksikan pemahaman tentang kekayaan sumber daya hayati Bali berupa tanaman obat yang dapat dioptimalkan menjadi obat-obatan herbal; (2) pengembangan Usada Bali yang bersumber dari Ayurweda adalah refleksi pemahaman kekayaan pengetahuan lokal Hindu-Bali di bidang kesehatan; (3) wacana membuka loket khusus bagi balian di rumah sakit menunjukkan upaya mendorong penguatan eksistensi Usada Bali dalam institusi kesehatan modern atau mediasi ruang publik kesehatan; dan (4) wacana sertifikasi balian yang akan praktik di rumah sakit menunjukkan upaya pemenuhan atas regulasi negara, khsusnya UU No. 36 Tahun 2004 bahwa tenaga kesehatan yang boleh melakukan praktik di rumah sakit harus memiliki sertifikat, termasuk tenaga kesehatan 
tradisional yang memiliki keterampilan. Jadi, keempat simpul wacana tersebut menegaskan upaya penguatan eksistensi Usada Bali dalam dunia kesehatan.

Dukungan serupa juga disampaikan

Yahya Ansori, seorang pemerhati masalah sosial-kesehatan, dalam artikelnya, "Memadukan Pelayanan Pengobatan Tradisional dan Modern di Rumah Saki: Mungkinkah?” (BALI EXPRESS, Jumat, 29

Maret 2019) yang menyatakan:

"Kendati memiliki kontribusi positif dalam memecahkan permasalahan kesehatan masyarakat Bali, sistem medis usada Bali saat ini masih dalam kondisi stagnan, jalan di tempat. Keberadaannya termarjinalkan oleh sistem pelayanan medis modern (Barat). Oleh karena itu, sudah sepantasnya bilamana sistem medis usada Bali lebih diperhatikan, dijaga kelestariannya, dan dikembangkan. Wacana untuk mengkolaborasikan pelayanan pengobatan usada Bali oleh balian di Rumah Sakit (RS) adalah sahsah saja, namun perlu didahului studi kelayakan, mengingat masing-masing memiliki kedirian (otonom) tersendiri, yang tidak bisa diintegrasikan begitu saja. Diperlukan koordinasi secara intensif yang melibatkan semua pihak termasuk pihak manajemen RS, balian, pengamat, dan pihak lainnya guna membahas: berkenankah para balian buka praktik dalam satu atap di RS?; bagaimana sistem manajemen 'yang pas' untuk kolaborasi pelayanan kesehatan tradisional dan modern di RS."

Pernyataan tersebut menunjukkan pengakuan bahwa sistem pengobatan Usada Bali telah memberikan kontribusi positif dalam memecahkan permasalahan kesehatan masyarakat Bali, walaupun keberadaannya saat ini cenderung stagnan karena sistem medis modern (Barat) lebih mendominasi. Oleh karena itu, menjadi suatu kewajaran apabila sistem Usada Bali harus diperhatikan, dijaga, dilestarikan, dan dikembangkan.
Pengembangan Usada Bali dalam wacana kolaborasinya dengan medis modern dapat dipandang sebagai upaya penguatan eksistensi Usada Bali. Walaupun harus didasari studi kelayakan terutama dalam konteks otonomi pengetahuan dan praktik pengobatan yang menjadi diskursus penting dalam modernitas. Jadi, penguatan eksistensi Usada Bali dalam ruang publik kesehatan niscaya terwujud apabila berhasil dikoordinasikan dengan sistem manajemen medis modern.

\section{Penutup}

Berdasarkan penjelasan di atas dapat dipahami bahwa masa depan Usada Bali dalam wacana modernitas tergantung pada kemampuan berbagai elemen yang terlibat di dalamnya untuk merespons nilai-nilai budaya modern. Kepercayaan masyarakat, kekayaan pengetahuan, dan regulasi negara memberikan peluang untuk itu, tinggal bagaimana cara memanfaatkan peluang tersebut. Setidaktidaknya, terdapat tiga aspek penting yang menentukan masa depan Usada Bali dalam wacana modernitas, yaitu (1) kemampuan para balian untuk mengoptimalisasikan kepercayaan masyarakat melalui narasi diri dalam rangka meningkatkan daya tawarnya pada jasa pelayanan kesehatan; (2) pemosisian Usada Bali dalam wacana ilmiah, baik melalui lembaga pendidikan maupun kelompokkelompok sekunder yang memiliki perhatian dan kepedulian pada pengembangan Usada Bali; dan (3) kapitalisasi regulasi negara sebagai pijakan legal-formal untuk mengembangkan Usada Bali, baik dalam konteks pengetahuan maupun praksis. Adaptasi dialektis terhadap nilai-nilai modern meniscayakan bagi Usada Bali untuk meraih

E-Jurnal Widya Kesehatan ,Volume 1, Nomor ; 2 Oktober 2019 
masa depan yang lebih baik dalam wacana modernitas.

\section{Daftar Pustaka}

Abraham, Francis M. 1991. Modernisasi di Dunia Ketiga: Suatu Teori Umum Pembangunan. Yogyakarta: Tiara Wacana.

Bourdieu, Piere. 2010. Aneka Produksi Kultural Sebuah Kajian Sosiologi Budaya. Yogyakarta: Kreasi Wacana.

Foster, George M. \& Barbara Gallatin Anderson. $1978 . \quad$ Medical Anthropology. New York: John Willey and Son.

Giddens, Anthony. 2011. Konsekuensikonsekuensi Modernitas. Yogyakarta: Kreasi Wacana.

Hardiman, F. Budi. 2009. Kritik Ideologi. Yogyakarta: Kanisius.

Harisson, Lawrence E. dan Samuel P. Huntington (Ed.). 2006. Kebangkitan Peran Budaya. Bagaimana Nilai-nilai Membentuk Kemajuan Manusia. Jakarta: LP3ES.

Harker, Richard; Cheeelen Mahar; Chris Wilkes. 2009. (Habitus x Modal) +
Ranah $=$ Praktik, Pengantar Paling Komprehensif Kepada Pemikiran Pierre Bourdieu. Yogyakarta: Jalasutra.

Hobart, Angela. 1998. "Literate healers and wayang Calon Arang: flux, transformation and renewal" dalam Proses dan protes budaya: Persembahan untuk Ngurah Bagus. Penyunting: Aron Meko Mbete, dkk. Denpasar: Pustaka Bali Post, p. 2131.

Mahar, Cheleen dkk. 2009. "Posisi Teoretis Dasar". Ed. Bagus Takwin. Pengantar Paling Komprehensif kepada Pemikiran Pierre Bourdieu. Yogyakarta: Jalasutra.

Kalangie, S. Nico. (1994). Kebudayaan dan Kesehatan; Pengembangan Pelayanan Kesehatan Primer Melalui Pendekatan Sosiobudaya. Jakarta: PT Kesaint Blanc Indah Corp.

Nala, Ngurah. 1993. Usada Bali. Denpasar: Upada Sastra.

Triguna, Ida Bagus Gde Yudha. 2003. Teori-teori Pembangunan. Denpasar: Widya Dharma. 